\title{
The use of mixed effluent liquid wastes as a source of valuable nutrients
}

\author{
M. P. Zacharof ${ }^{1} \&$ R. W. Lovitt ${ }^{2}$ \\ ${ }^{1}$ College of Engineering, Swansea University, UK \\ ${ }^{2}$ College of Engineering, Centre for Complex Fluids Processing, UK
}

\begin{abstract}
The recovery of valuable nutrients, from waste sources allows carbon based materials to be recycled and reused through the production of organic materials. For example, phosphate and ammonia can be directly applied in a wide range of fields in today's industrial world including their use in the fertilizers production industry, textiles, cosmetics in the food industry. The aim of this research is the ability to recover these sources from waste processes, such as anaerobic digestion and promote these materials in the industry. These neutral processes will provide valuable carbon neutral processes that are highly beneficial for the environment as provide industry with materials and reasonable cost.

Keywords: waste process, nutrients, particle size, dry matter, ammonia, phosphate, environment, conductivity, salinity, sludge.
\end{abstract}

\section{Introduction}

Several studies have shown possible environmental and commercial benefits using mixed stream effluents, deriving from different sources, as a potential source for valuable nutrients. These benefits include the relief of municipal treatment plants, the use of favourable nutrients and the composition of urine free wastewater for biotreatment [1-3]. In anaerobic processes the hydrolysis of target solid wastes followed by the microbial conversion of them to biodegradable organic content results in the production of intermediate organic acids, specifically carboxylic acids. These acids are detected at high concentrations in the effluent streams and mixed liquors of anaerobic membrane reactor systems. Other useful nutrients include phosphate and ammonia [4-6]. 
Stabilisation of sludge at large wastewater treatment plants is usually carried out by anaerobic digestion. Mainly, it has been employed to stabilize the suspended organic material (sludge) and to provide a source of energy [7, 8]. Anaerobic digestion is also used for the generation of biogas for electricity, especially using agricultural waste. During this process organic matter is transformed into methane gas $\left(\mathrm{CH}_{4}\right)$ and carbon dioxide $\left(\mathrm{CO}_{2}\right)$ by the action of different groups of bacteria. The main advantages of this process are the reduction in the volume of waste sludge and the production of methane gas $\left(\mathrm{CH}_{4}\right)$ that can be utilised to supply energy. The simultaneous release of ammonia due to organic matter hydrolysis should be considered to properly perform the mass balances [9-11]. These ions are also considered to be considerable market value which emerges the need for their recovery [6, 12-14].

In the United Kingdom but also in the United States and Europe, the generation of electricity through biogas production is an ongoing tendency, while the amount of effluents been disposed in the land, as a result of this process, is constantly augmenting. The potential environmental dangers due to eutrophication but also the current environmental legislation emerged the need for a sophisticated treatment strategy of these effluents. In addition, valuable materials such as phosphate and ammonia can be potentially recovered and reused. Phosphate rock is a non-renewable natural resource [3, 15-18].

It is mainly found in sedimentary and igneous deposits, its sustainable production and management is of critical importance. By 2035 it is calculated that the demand for phosphorus map will outpace the supply. Being a finite resource is becoming increasingly expensive $(800 \%$ rise between 2006 and 2008 , $\$ 50$ to $\$ 400$ ). Its current value is over $\$ 500$ per ton. Although its production is carbon neutral it's been achieved by mining causing environmental and social issues [5-8, 19-21].

On the other hand, global ammonia consumption has reached 153 million tonnes. Ammonia production has a large carbon footprint as during its production methane is reformed to produce hydrogen and carbon dioxide. About 3 tonnes of $\mathrm{CO}_{2}$ are produced per tonne of ammonia (9 plants in West Europe). The current market value of a tonne is about $\$ 800$, while in 2007 the price reached $\$ 1500$. Ammonia recovery would therefore save $\mathrm{CO}_{2}$ production by reducing environmental impact [22-25].

The aim of this research is to examine the possibility of using anaerobically digested fluids and wastewater sludge as a source of useful nutrients. The useful nutrients could be recovered using filtration technology. As such, size related properties were also examined. For this purpose two different sludge samples were selected and physicochemically characterized.

\section{Materials and methods}

\subsection{Sludge samples}

The samples were collected from two locally based companies. The sludge deriving from municipal wastewater was collected from Dwr Cymru - Welsh 
Water treatment plant in Cog Moors, Cardiff, Wales, United Kingdom. The effluents deriving were collected after the automatic separator connected with the output line of the digester and before the dewatering treatment. The effluents were collected in $25 \mathrm{~L}$ capacity plastic jerry cans and were left to settle for $24 \mathrm{~h}$ before any handling or treatment. The sludge deriving from agricultural and animal was collected from Farm Renewable Environmental Energy Limited (Fre), Wrexham, Wales, United Kingdom. The sludge was deriving from animal and agricultural waste sources. The effluents deriving are collected after the automatic waste separator connected with the output line of the anaerobic digester. The effluents were collected in $25 \mathrm{~L}$ capacity plastic jerry cans and were left to settle for $24 \mathrm{~h}$ before any handling or treatment.

\subsection{Analysis of dry matter content and physicochemical characteristics}

Dry matter (DM\%), total solids (TS, g/L), total suspended solids (TSS, g/L), were determined according to APHA [18]. Particle size distribution (PSD) of sludge samples was determined by light scattering technique using Mastersizer 2000 (Malvern, UK), the zeta potential was determined by the Zetasizer (Malvern, UK), the conductivity and salinity of the samples were measured used a conductivity meter (Rusell systems) calibrated with a standard solution of $0.1 \mathrm{M}$ of $\mathrm{KCl}$.

\subsection{Analysis of chemical content}

All the sludge samples were analyzed for ammonia and phosphate content. The methods used were according to APHA [18].

\section{Results and discussion}

\subsection{Mixed effluent streams-the case of agricultural mixed effluent stream}

The physical characteristics of agricultural mixed effluent stream had to be examined in order to decide whether the sludge could be filterable. In separation processes using filtration technology, the clogging and fouling of the membrane is the greatest disadvantage. Certainly, certain measures can be taken to avoid this phenomenon, such as pretreatment of the fluids, development of cleaning strategies and back flushing of the membranes. The filterability of the sludge though had been examined prior to any strategy developed. As such, tests were conducted regarding the physical and chemical characteristics of the sludge (Table 1).

In an effort to partially remove the solids but also to enhance the content of ammonia and phosphate in the samples, dilution with water was used. Furthermore, the effect of $\mathrm{pH}$ of the samples on phosphate and ammonia was tested.

As it can be seen from the previously stated results, the agricultural sludge is potentially filterable. The content of dry matter and total solids imply a rather thin semi liquid stream. Dilution is a proven adequate approach for partial 
Table 1: $\quad$ Physical characteristics of agricultural sludge.

\begin{tabular}{|c|c|c|c|c|c|c|c|c|c|}
\hline $\begin{array}{c}\text { Agricultural } \\
\text { Sludge Samples }\end{array}$ & $\begin{array}{c}\text { Overall } \\
\text { Dilution } \\
\text { Factor }\end{array}$ & $\begin{array}{c}\text { Concto } \\
\text { orig. } \\
(\%)\end{array}$ & $\begin{array}{c}\text { Dry matter } \\
(\text { Wdm, } \%)\end{array}$ & $\begin{array}{c}\text { Total } \\
\text { Solids } \\
(\mathrm{TS}, \mathrm{g} / \mathrm{L})\end{array}$ & $\begin{array}{c}\text { Total } \\
\text { Suspends } \\
\text { Solids (TSS, } \\
\mathrm{mg} / \mathrm{L})\end{array}$ & $\begin{array}{c}\text { Conductivity } \\
(\mathrm{mS} / \mathrm{cm}-1)\end{array}$ & $\begin{array}{c}\text { Salinity } \\
(\%)\end{array}$ & $\begin{array}{c}\text { Zeta } \\
\text { Potential } \\
(\mathrm{mV})\end{array}$ & $\begin{array}{c}\text { Size } \\
(\mu \mathrm{m})\end{array}$ \\
\hline $\begin{array}{c}\text { Raw Sludge } \\
(50 \% \text { Dil, 24h } \\
\text { Sedimentation) }\end{array}$ & 2 & 50 & 1.5133 & 15.133 & 252.62 & 9.11 & 5.1 & -33.25 & 13.97 \\
\hline $\begin{array}{c}\text { Diluted Sample } \\
\text { A (1:1 Dil.) }\end{array}$ & 4 & 25 & 0.977 & 9.776 & 202.82 & 5.16 & 2.6 & -29.60 & 9.703 \\
\hline $\begin{array}{c}\text { Diluted Sample } \\
\text { B (1:1 Dil.) }\end{array}$ & 6 & 12.5 & 0.5115 & 5.116 & 183.80 & 3.41 & 1.8 & -29.43 & 8.127 \\
\hline $\begin{array}{c}\text { Diluted Sample } \\
\text { C (1:1 Dil.) }\end{array}$ & 8 & 6.25 & 0.2661 & 2.662 & 174.54 & 2.88 & 1.5 & -25.97 & 4.933 \\
\hline
\end{tabular}

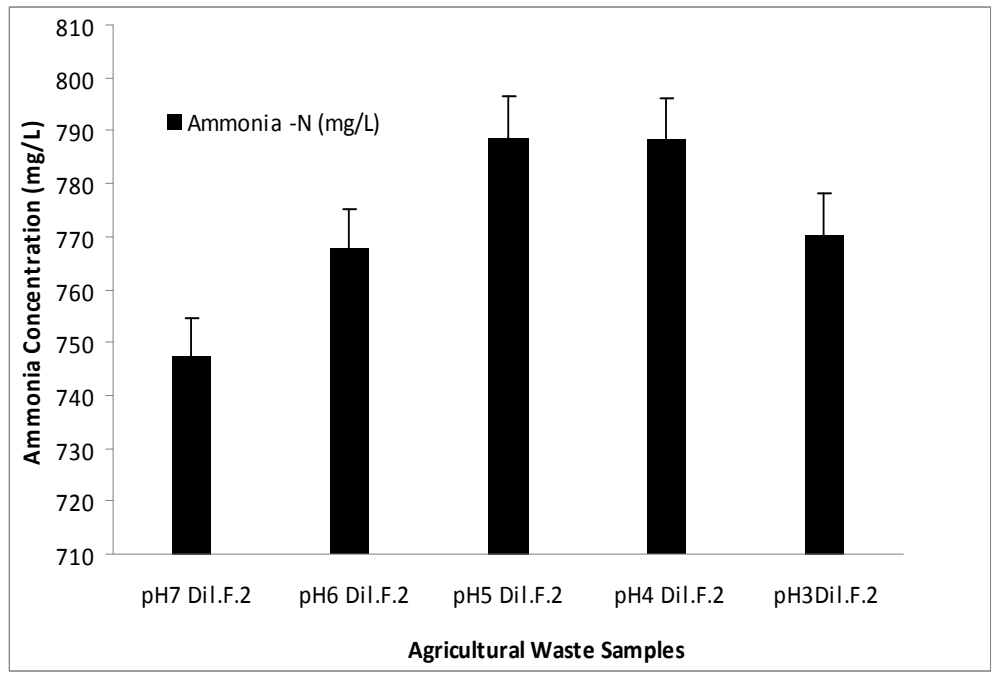

Figure 1: Ammonia concentration in acidified and diluted sludge.

removal of solids and could be used as a pretreatment process to any separation strategy followed, as high content of solid matter might interfere with any separation method used. The sludge also contains a significant amount of ammonia and phosphate. The concentration of ammonia in agricultural sludge is $5027.30 \mathrm{mg} / \mathrm{L}$ of wet sludge, and the content in phosphate is $216.3 \mathrm{mg} / \mathrm{L}$ of wet sludge. This source is rich is ammonia and phosphate, though these nutrients are attached to the solids, which make their recovery a challenging task. As such, it was proposed to use dilution with water but also acidification in an effort to remove these nutrients from the pellets (Figures 1 and 2). Acidification when 


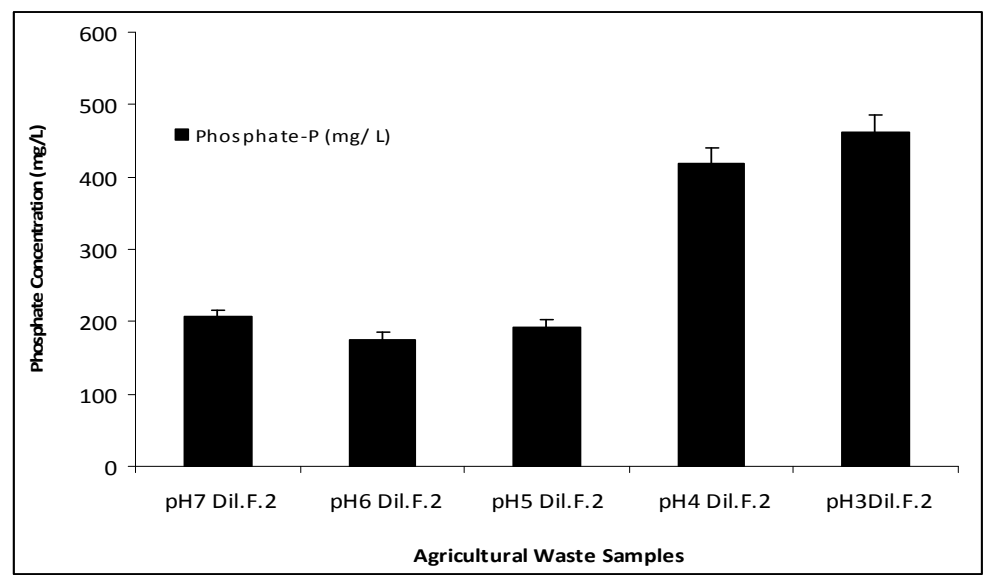

Figure 2: $\quad$ Phosphate concentration in acidified and diluted sludge.

combine in dilution, enhances the content of ammonia and phosphate in the supernatant of the sludge. As such these effluents are a valuable source of nutrients, the next step being a development of a judicious strategy of their recovery.

\subsection{Mixed effluent streams-the case of municipal wastewater mixed effluent stream}

The same approach was taken to test the municipal wastewater sludge. In this case, the discharge from ammonia and phosphate content has obvious environmental benefits as well as health related benefits for the general population. The disposal of discharged sludge in the land is reassuring high level of water quality that ensures the wellbeing of the general population. The physical and chemical characteristics have been tested (Table 2). The amount of ammonia in municipal wastewater sludge is $2030.5 \mathrm{mg} / \mathrm{L}$ of wet sludge, and the concentration in phosphate is $336.2 \mathrm{mg} / \mathrm{L}$ of wet sludge. Although the content of ammonia is significantly lower when compared to the agricultural waste, the high content in phosphate, is suggesting that this sludge is a potential source for phosphate recovery. Combining all the previously referred results, it can be assumed the wastewater can be used as a source of ammonia and phosphate.

Mixed effluent waste streams deriving from various sources are considered to be an attractive source of chemicals. Two samples of such streams, deriving from municipal wastewater and agricultural waste, were tested for ammonia and phosphate content. Their physicochemical properties were tested as a potential recovery method of these substances is filtration. Filterability of these streams had to be examined as these fluids do normally contain a high amount of solids that needs a judicious pretreatment strategy in order to be removed. The effluents tested were proven rich in phosphate and ammonia and with a relatively low 
content of the solids which makes them attractive candidates for development of a separation state.

Table 2: $\quad$ Physical characteristics of municipal wastewater sludge.

\begin{tabular}{|c|c|c|c|c|c|c|c|c|c|}
\hline $\begin{array}{c}\text { Agricultural } \\
\text { Sludge } \\
\text { Samples }\end{array}$ & $\begin{array}{c}\text { Overall } \\
\text { Dilutio } \\
\mathrm{n} \\
\text { Factor }\end{array}$ & $\begin{array}{c}\text { Conc } \\
\text { to } \\
\text { orig. } \\
(\%)\end{array}$ & $\begin{array}{c}\text { Dry } \\
\text { matter } \\
(\mathrm{Wdm}, \\
\%)\end{array}$ & $\begin{array}{c}\text { Total } \\
\text { Solids } \\
(\mathrm{TS}, \\
\mathrm{g} / \mathrm{L})\end{array}$ & $\begin{array}{c}\text { Total } \\
\text { Suspends } \\
\text { Solids } \\
(\mathrm{TSS}, \\
\mathrm{mg} / \mathrm{L})\end{array}$ & $\begin{array}{c}\text { Cond } \\
\text { uctivit } \\
\mathrm{y} \\
(\mathrm{mS} / \mathrm{c} \\
\mathrm{m}-1)\end{array}$ & $\begin{array}{c}\text { Salini } \\
\text { ty } \\
(\%)\end{array}$ & $\begin{array}{c}\text { Zeta } \\
\text { Poten } \\
\text { tial } \\
(\mathrm{mV})\end{array}$ & $\begin{array}{c}\text { Size } \\
(\mu \mathrm{m})\end{array}$ \\
\hline $\begin{array}{c}\text { Raw Sludge } \\
\text { (50\% Dil, 24h } \\
\text { Sedimentation } \\
\text { (1) }\end{array}$ & 2 & 50 & 3.466 & $\begin{array}{c}34.65 \\
9\end{array}$ & 307.900 & 2.930 & 0.90 & -17.8 & 55.710 \\
\hline $\begin{array}{c}\text { Diluted } \\
\text { Sample A (1:1 } \\
\text { Dil.) }\end{array}$ & 4 & 25 & 3.419 & $\begin{array}{c}34.19 \\
1\end{array}$ & 297.500 & 2.650 & 1.08 & -11.7 & 52.337 \\
\hline $\begin{array}{c}\text { Diluted } \\
\text { Sample B (1:1 } \\
\text { Dil.) }\end{array}$ & 6 & 12.5 & 1.182 & $\begin{array}{c}11.81 \\
8\end{array}$ & 284.000 & 1.901 & 0.80 & -10.9 & 40.146 \\
\hline $\begin{array}{c}\text { Diluted } \\
\text { Sample C (1:1 } \\
\text { Dil.) }\end{array}$ & 8 & 6.25 & 0.500 & 5.004 & 304.600 & 0.945 & 0.50 & -10.5 & 38.111 \\
\hline
\end{tabular}

\section{Acknowledgement}

Special acknowledgements are given to Mr. M. Gerardo, for his help in the analysis of nutrients of the waste sources.

\section{References}

[1] Pronk, W., Palmquist, H., Biebow, M., Boller, M. (2006). "Nanofiltration for the separation of pharmaceuticals from nutrients in source-separated urine." Water Research 2006: 1405-1412.

[2] Maurer, M., Pronk, W., Larsen, T.A. (2006). "Treatment processes for source-separated urine." Water Research 40: 3151-3166.

[3] Deminer, G. N., Chen, S. (2005). "Two-phase anaerobic digestion of unscreened dairy manure." Process Biochemistry 40: 3542-3549.

[4] Li, Y., Park,S.Y., Zhu, J. (2011). "Solid-state anaerobic digestion for methane production from organic waste." Renewable and Sustainable Energy Reviews 15: 821-826.

[5] Katikaneni, S. P., Cheryan, M. (2002). "Purification of fermentationderived acetic acid by liquid-liquid extraction and esterification." Industrial Engineering Chemical Resources 41(2745-2752).

[6] Lipnizki, J. (2008). "Optimisation of membrane processes in white biotechnology. " Desalination 224: 105-110.

[7] Siddharth, S. (2006). "Green energy-anaerobic digestion”. 4th WSEAS International Conference on Heat Transfer, Thermal Engineering and Environment, Elounda, Greece. 
[8] Pastor, L., Marti, N., Bouzas, A., Seco, A. (2008). "Sewage sludge management for phosphorus recovery as struvite in EBPR wastewater treatment plants." Bioresource Technology 99: 4817-4824.

[9] Boyaval, P., Corre, C. (1995). "Production of propionic acid." Lait 75: 453-461.

[10] Chang, R. “Chemistry” 6th edition, McGraw Hill, pp: 152-365, 1998.

[11] Jevons, K., Awe, M. (2010). "Economic benefits of membrane technology vs. evaporator.” Desalination 250: 961-963.

[12] Li, Y., Park,S.Y., Zhu, J. (2011). "Solid-state anaerobic digestion for methane production from organic waste." Renewable and Sustainable Energy Reviews 15: 821-826.

[13] Pastor, L., Mangin, D., Ferrer, J., Seco, A. (2010). "Struvite formation from the supernatants of an anaerobic digestion pilot plant." Bioresource Technology 101: 118-125.

[14] Kim, J.-O., Somiya, I., Shin, E.-B., Bae, W., Kim, S.-K.., Kim, R.-H. (2002). "Application of membrane-coupled anaerobic volatile fatty acids fermentor for dissolved organics recovery from coagulated raw sludge." Water Science and Technology 45(23): 167-174.

[15] Dinsdale, R. M., Premier, G.C., Hawkes, F.R., Hawkes, D.L. (2000). "Twostage anaerobic co-digestion of waste activated sludge and fruit/vegetable waste using inclined tubular digesters." Bioresource Technology 72: 159168.

[16] Hong, S. U., Ouyang, L., Bruening, M.L. (2009). "Recovery of phosphate using multilayer polyelectrolyte nanofiltration membranes." Journal of Membrane Science 327: 2-5.

[17] Ugwuanyi Obeta, J., Harvey, L.M., McNeil, B. (2005). "Effect of digestion temperature and $\mathrm{pH}$ on treatment efficiency and evolution of volatile fatty acids during thermophillic aerobic digestion of model high strength agricultural waste." Bioresource Technology 96: 707-719.

[18] Standard Methods for the Examination of Water and Wastewater published jointly American Public Health Association(APHA), American Water Works Association, Water Environment Federation, Lenore S. Clesceri, Arnold E. Greenberg Andrew D. Eaton Mary Ann H. Franson 20th Ed. , pp:5-104 -5-200 1998.

[19] Kosutic, K., Kunst, B. (2002). "Removal of organics from aqueous solutions by commercial $R O$ and $N F$ membranes of characterized porosities. " Desalination 142: 47-56.

[20] Masse, L., Masse, D.I., Pellerin, Y. (2007). "The use of membranes for the treatment of manure: a critical literature review." Biosystems Engineering 98: 371-380.

[21] Nishio, N., Nakashimada, Y. (2007). "Recent development of anaerobic digestion processes for energy recovery from wastes." Journal of Bioscience and Bioengineering 103: 105-112.

[22] Masse, L., Masse, D.I., Pellerin, Y. (2008). "The effect of $p H$ on the separation of manure nutrients with reverse osmosis membranes.” Journal of Membrane Science 325: 914-919. 
342 Waste Management and the Environment VI

[23] Kimura, K. et al. (2003). "Rejection of micropollutants (disinfection by products, endocrine disrupting compounds and pharmaceutically active compounds) by NF/RO." Journal of Membrane Science 227: 113-121.

[24] Mshandele, A. M., et al. (2008). "Two-stage anaerobic digestion of aerobic pre-treated sisal leaf decortications residues: hydrolases activities and biogas production." African Journal of Biochemistry Research 11: 211218.

[25] Kim, J.-O., Somiya, I., Shin, E.-B., Bae, W., Kim, S.-K.., Kim, R.-H. (2002). "Application of membrane-coupled anaerobic volatile fatty acids fermentor for dissolved organics recovery from coagulated raw sludge." Water Science and Technology 45(23): 167-174. 